\title{
Rancang Bangun Sistem Informasi Housekeeping Inventory dengan Metode Waterfall
}

\author{
Muhammad Faisal \\ Universitas Bina Sarana Informatika \\ e-mail: muhammad.mal@bsi.ac.id
}

\begin{abstract}
Abstrak - Perusahaan Property memiliki beberapa portofolio bisnis, salah satunya adalah Property Services yang meliputi bidang kerja housekeeping. Dalam pelaksanaan operasional housekeeping dibutuhkan adanya inventarisasi barang-barang penunjang kerja. Saat ini inventarisasi barang-barang tersebut berjalan secara manual. Sistem informasi yang berjalan secara manual berpotensi terjadi adanya disintegrasi antara data tertulis dengan kondisi riil. Perkembangan teknologi informasi yang mengarah pada digitalisasi juga membuat sistem manual mulai banyak ditinggalkan. Maka dari itu, diperlukan suatu sistem informasi terkomputerisasi untuk mengeliminir disintegrasi dan mengatasi ketertinggalan. Dalam membangun sistem informasi terkomputerisasi ini kami menggunakan metode penelitian pengembangan perangkat lunak waterfall dan teknik pengumpulan data dengan melakukan observasi, wawancara dan studi pustaka. Adapun perangkat lunak pendukung yang digunakan untuk membangun aplikasi sistem informasi housekeeping inventory ini adalah Netbeans IDE 8.2 dan MySQL database server. Berdasarkan implementasi yang telah dilakukan, sistem informasi housekeeping inventory dapat menghasilkan keluaran sesuai kebutuhan manajemen perusahaan berupa laporan penggunaan barang, laporan Logbook dan pengajuan barang secara akurat, efisien dan relevan.
\end{abstract}

Kata kunci : Inventaris HouseKeeping; Waterfall; Sistem Informasi.

Abstract - Property companies have several business portfolios, one of which is Property Services which includes housekeeping. In carrying out housekeeping operations an inventory of work support items is required. Currently the inventory of these items is running manually. Manually running information systems have the potential to cause disintegration between written data and real conditions. The development of information technology that led to digitization also made many manual systems become obsolete. Therefore, a computerized information system is needed to eliminate disintegration and overcome backwardness. In building this computerized information system we used waterfall software development research methods and data collection techniques by conducting observations, interviews and literature studies. The supporting software used to build the housekeeping inventory information system application is Netbeans IDE 8.2 and MySQL database server. Based on the implementation that has been carried out, the housekeeping inventory information system can produce output according to the needs of the company's management in the form of goods usage reports, Logbook reports and the submission of goods accurately, efficiently and relevantly

Keywords : HouseKeeping Inventory; Waterfall; System Information.

\section{PENDAHULUAN}

PT. Telkom Property merupakan perusahaan yang bergerak di bidang jasa pengelolaan gedung dengan menyediakan tenaga kerja Security and Parking, Mechanical Electrical (ME), Housekeeping, dan Office Boy $(O B)$. Selain itu, perusahaan ini juga melayani penyediaan transportasi dan penyewaan gedung. Sebagai salah satu anak perusahaan PT. Telkom Indonesia, tbk, dimana perusahaan BUMN ini melekat dengan Bidang IT, maka digitalisasi dengan sistem komputerisasi manajemen pada PT. Telkom Property merupakan hal fundamental yang tidak bisa diabaikan mengingat saat ini telah beranjak satu tahun diimplementasikannya Sistem Informasi Absensi berbasis website terintegrasi mobile app (Sunfish Go) dan pelaporan checklist online menggunakan mobile app My Birawa. Langkah tersebut merupakan dua buah indikasi bahwa manajemen perusahaan mulai menyadari jika peradaban dunia tengah mengalami perubahan kearah penggunaan teknologi informasi secara pesat. Sistem berasal dari bahasa Latin (syst ma) dan bahasa yunani (sust ma) yang mempunyai makna suatu kesatuan yang terdiri dari komponen atau elemen yang dihubungkan bersama untuk memudahkan aliran informasi, materi atau energi untuk mencapai suatu tujuan, Eriyatno dalam (Rusmawan, 2019:28). Menurut Hutahaean (2015:9), "Informasi adalah data yang diolah lebih berguna dan lebih berarti bagi 
penerimanya. Sumber informasi adalah data kenyataan yang menggambarkan suatu kejadian-kejadian dan kesatuan nyata. Kejadian-kejadian adalah kejadian yang terjadi pada saat tertentu". Menurut Abdul Kadir dalam (Saputra \& Bukhori, 2014:7), "Informasi dapat didefinisikan sebagai hasil dari pengolahan data dalam suatu bentuk yang lebih berguna dan lebih berarti bagi penerimanya yang menggambarkan suatu kejadiankejadian (event) yang nyata (fact) yang digunakan untuk pengambilan keputusan". Menurut O'brien dalam (Rusmawan, 2019:33), mengemukakan bahwa "Sistem informasi adalah gabungan yang terorganisasi dari manusia, perangkat lunak, perangkat keras, jaringan komunikasi dan sumber data dalam mengumpulkan, mengubah, dan menyebarkan informasi dalam organisasi”. Menurut Bash (2015:9), "Sistem informasi adalah suatu sistem di dalam suatu organisasi yang mempertemukan kebutuhan pengolahan transaksi harian yang mendukung fungsi operasi organisasi yang bersifat manajerial dengan kegiatan strategi dari suatu organisasi untuk dapat menyediakan kepada pihak luar tertentu dengan laporan yang diperlukan".. Sistem informasi dikembangkan sesuai kebutuhan penggunanya, salah satunya dalam hal pengelolaan inventory barang. Berdasarkan paparan diatas, maka kami melihat peluang untuk membangun sebuah Sistem Informasi yang berkaitan dengan pengadaan barang seperti peralatan kerja, chemical, pengharum ,dan tissue dalam pelaksanaan Housekeeping, dimana saat ini masih berjalan secara manual. Sistem yang berjalan secara manual ini akan diubah menuju sistem terkomputerisasi dalam bentuk desktop. Sehingga, seluruh pengelolaan data terkait barang-barang Housekeeping akan terorganisir dengan tertib dan teratur, menegaskan validasi stok, serta membantu dalam pelaporan bulanan maupun tahunan.Menurut Rusmawan (2019:40), Basis data didefinisikan sebagai "Kumpulan data yang saling berhubungan yang disimpan secara bersama sedemikian rupa tanpa pengulangan (redundancy) yang tidak perlu, untuk memenuhi kebutuhan".

Secara umum komponen basis data terdiri dari hal-hal berikut :

1. Hardware, sebagai pendukung operasi pengolahan data seperti CPU, memori, disk, terminal dan sebagainya.

2. Software sistem operasi, (Windows, Linux, Unix dan sistem operasi lainnya).

3. Software pengelola basis data (DBMS), seperti MS-Access, SQL, Oracle, mySQL, DB2, informix, sybase, postgree, IBM, AS400 dan sejenisnya. 4. Software program aplikasi misalnya Visual Basic, Delphi, Visual Foxpro, php dan lain-lain.

5. Basis data (semua data yang diperlukan, dipelihara, dikelola oleh sistem Basis Data)

\section{Pemakai atau pengguna basis data (user )}

Java merupakan bahasa pemrograman tingkat tinggi yang berorientasi pada objek dan program Java tersusun dari bagian yang disebut class. Class terdiri dari metode-metode yang melakukan pekerjaan dan mengembalikan informasi setelah melakukan tugasnya. Java API telah menciptakan applet dan aplikasi canggih dengan menyediakan fungsionalitas yang memadai. Dalam mempelajari Java ada dua hal yang harus dipahami yaitu bagaimana mempergunakan class pada Java API dan mempelajari bahasa Java. Java adalah bahasa pemrograman yang dapat membuat seluruh bentuk aplikasi tidak hanya desktop dan web namun juga bisa membuat aplikasi mobile dan lainnya. Java memiliki konsep yang disebut "write once run everywhere". Netbeans adalah sebuah aplikasi Integrated Development Environment (IDE) yang berbasiskan Java dari Sun Mycrosystem yang berjalan diatas swing. Swing merupakan sebuah teknologi Java untuk pengembangan aplikasi desktop yang dapat berjalan pada berbagai macam platform seperti Windows, Linux, Mac OS X dan Solaris. Sebuah IDE merupakan lingkup pemrograman yang diintegrasikan ke dalam suatu aplikasi perangkat lunak yang menyediakan Graphic User Interface (GUI), suatu kode editor atau text, suatu compiler dan suatu debugger. Netbeans juga dapat digunakan programmer untuk menulis, meng-compile, mencari kesalahan dan menyebarkan program netbeans yang ditulis dalam bahasa pemrograman Java. Namun selain itu dapat mendukung bahasa pemrograman lainnya dan program ini pun bebas untuk digunakan dan untuk membuat profesional desktop, enterprise, web dan mobile applications dengan Java language, $\mathrm{C} / \mathrm{C}++$ dan bahkan dynamic languages seperti PHP, JavaScript, Groovy dan Ruby. MySQL adalah sebuah perangkat lunak sistem manajemen bisnis SQL (Database Management System) atau DBMS yang multithread, multi-user, dengan sekitar 6 juta instalasi di seluruh dunia. MySQL AB membuat MySQL tersedia sebagai perangkat lunak gratis dibawah lisensi GNU General Public License (GPL), tetapi mereka juga menjual dibawah lisensi komersil untuk kasus-kasus dimana penggunanya tidak cocok dengan GPL.

\section{METODE PENELITIAN}

Metode Waterfall adalah sebuah metode pengembangan sistem dimana antar satu fase ke fase yang lain dilakukan secara berurutan. Dalam proses implementasi metode waterfall ini, sebuah langkah akan diselesaikan terlebih dahulu dimulai dari tahapan yang pertama sebelum melanjutkan ke tahapan yang berikutnya. Adapun keuntungan menggunakan metode waterfall yaitu requirement harus didefinisikan lebih 
mendalam sebelum proses coding dilakukan, selain itu proses implementasinya dilakukan secara bertahap dari tahap pertama hingga tahap terakhir secara berurutan. Disamping itu metode waterfall juga memungkinkan sedikit mungkin perubahan yang dilakukan oleh proyek yang sedang berlangsung. Adapun metode waterfall menurut Sommerville dalam (Sasmito, 2017) menjelaskan bahwa metode waterfall memiliki tahapan utama dari waterfall model yang mencerminkan aktifitas pengembangan dasar. Terdapat 5 (lima) tahapan pada metode waterfall, yaitu requirement analysis and definition, system and software design, implementation and unit testing, integration and system testing, dan operation and maintenance.

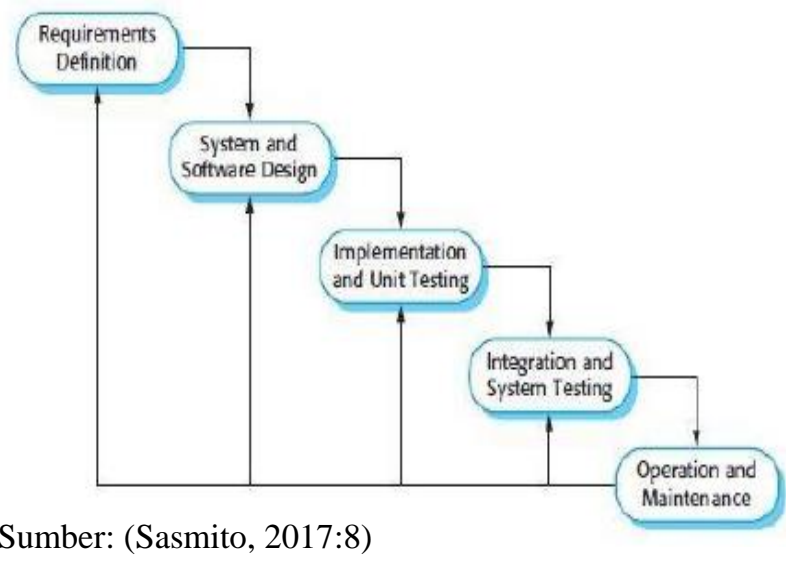

Gambar 1 Model Waterfall Menurut Sommerville

\section{Requirements analysis and definition}

Sistem houskeeping inventory pada PT. Telkom Property ini membutuhkan suatu sistem terkomputerisasi untuk mempermudah proses pengelolaan barang pada departement housekeeping agar proses keluar masuk barang beserta laporanlaporannya lebih tertib, teratur dan efisien.

2. System and software design

Tahapan perancangan sistem ini dilakukan setelah melakukan analisis kebutuhannya dengan menggunakan suatu tools untuk mempermudah menyusun dan mendisain sistem agar lebih terstruktur, rancangan yang dibuat seperti usecase sistem housekeeping inventory, activity login, dll. Tools program yang digunakan secara umum yaitu ERD, LRS dan UML menggunakan software Microsoft Visio dan Enterprise Architecture.

3. Implementation and unit testing

Pada tahap ini, perancangan perangkat lunak direalisasikan sebagai serangkaian program atau unit program yang dibuat dengan menggunakan bahasa 4 pemrograman Java dan menggunakan database MySQL serta Netbeans IDE sebagai tools editornya.
Pengujian menggunakan blackbox testing melibatkan verifikasi bahwa setiap unit memenuhi spesifikasinya.

\section{Integration and system testing}

Setiap unit program digabungkan dan diuji menggunakan metode blackbox testing seperti pada tahap sebelumnya, perbedaanya yakni pada tahap ini tidak membutuhkan pengetahuan tentang kode dan logika pemrogramman. Sistem diuji secara menyeluruh sebagai sebuah sistem lengkap untuk memastikan apakah sesuai kebutuhan atau tidak. Setelah pengujian selesai dilakukan, perangkat lunak dapat dikirimkan ke PT. Telkom Property untuk digunakan sebagaimana mestinya.

\section{Operation and maintenance}

Biasanya (walaupun tidak selalu), tahapan ini merupakan tahapan yang paling panjang. Program dipasang dan digunakan secara nyata. Maintenance melibatkan pembetulan kesalahan yang tidak di temukan pada tahapan-tahapan sebelumnya, meningkatkan implementasi dari unit sistem, dan meningkatkan layanan sistem sebagai suatu kebutuhan sistem yang baru.

\section{HASIL DAN PEMBAHASAN}

Sebagai salah satu anak perusahaan PT. Telkom Indonesia, tbk, dimana perusahaan BUMN ini melekat dengan bidang IT, maka digitalisasi dengan sistem komputerisasi manajemen pada PT. Telkom Property merupakan hal fundamental, akan tetapi berdasarkan dari penelitian kami, masih ada bagian atau departement kerja yang masih menggunakan sistem manual contohnya bagian inventory barang pada departemen housekeeping. Pada bagian ini apabila housekeeper ingin mengambil suatu barang atau peralatan tidak ada data atau dokumen yang merekam kegiatan pengambilan barang tersebut, biasanya hanya dilakukan secara lisan antara housekeeper dengan Leader, sehingga berpotensi ketidaksesuaian antara data stok barang dengan kondisi riil di lapangan.

\section{Prosedur Sistem Berjalan}

Prosedur Pengajuan Barang

a. Leader memeriksa stok barang, apabila stok barang kurang dari kebutuhan perbulan maka Leader membuatkan pengajuan barang.

b. Selanjutnya, pengajuan barang diserahkan ke Supervisor untuk dilakukan pengecekan sekaligus tanda tangan apabila pengajuan sesuai dengan kebutuhan yang diperlukan.

c. Kemudian diserahkan lagi ke General Affair untuk disetujui dan ditanda tangani.

d. Selanjutnya dilanjutkan ke Facility Manager untuk di tanda tangani. 
e. Terakhir dokumen dikirim ke kantor pusat untuk diajukan kepada supplier.

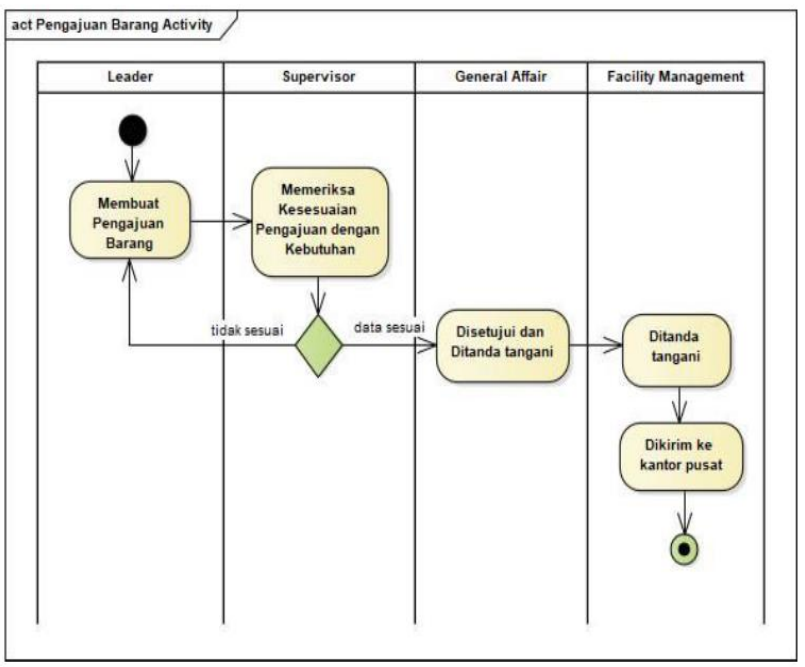

Gambar 2. Activity Pengajuan Barang Sistem Berjalan

\section{Prosedur Barang Masuk}

Supplier mengirim barang sesuai dokumen pengajuan barang, setelah barang sampai, surat jalan yang dibawa oleh kurir dicek oleh Leader dengan tujuan agar barang yang dikirim sesuai dengan yang diajukan.

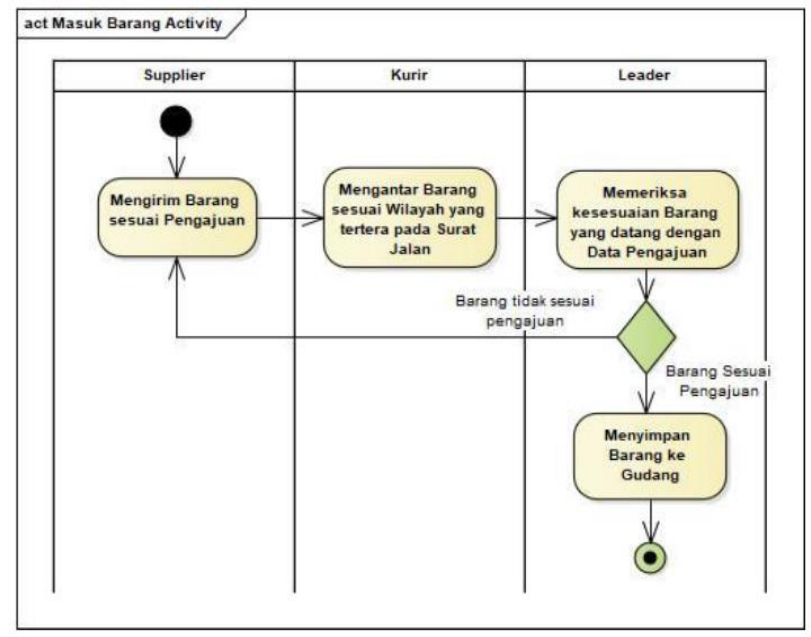

Gambar 3. Activity Masuk Barang Sistem Berjalan

\section{Prosedur Barang Keluar}

Pelaksana meminta izin kepada Leader untuk mengambil barang, selanjutnya barang diambil langsung oleh pelaksana dengan mengisi Logbook barang.

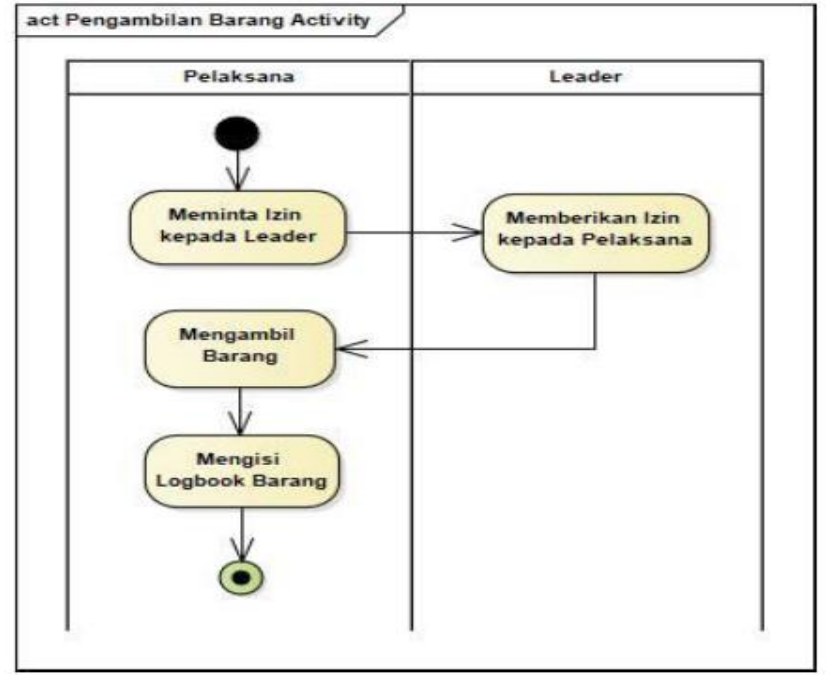

Gambar 4. Activity Barang Keluar Sistem Berjalan

\section{Tahapan Peracangan Sistem}

Analisi Kebutuhan Sistem

a. Kebutuhan Pengguna

Pengguna atau user merupakan orang-orang yang terlibat dalam penggunaan aplikasi housekeeping inventory ini yang berbasis desktop. Untuk pengoperasian aplikasi ini diperlukan beberapa orang yang terlibat diantaranya :

1. Admin, yang bertugas untuk mengelola seluruh data dan transaksi yang dilakukan oleh pelaksana.

2. Leader, bertugas mengawasi transaksi barang.

3. Supervisor, bertugas mengawasi jalannya sistem.

b. Kebutuhan Sistem

Adapun kebutuhan sistem yang diperlukan antara lain:

1. Semua pengguna harus melakukan Login terlebih dahulu dengan memasukkan username dan password sebelum menggunakan aplikasi.

2. Pengguna harus menambahkan barang ke daftar barang untuk proses pengambilan barang.

3. Sistem harus memenuhi kaidah perubahan stok.

4. Sistem harus menampilkan barang yang terdapat pada database.

5. Pengguna harus melakukan pengambilan barang agar data logbook terisi dan total pengajuan barang terkalkulasi secara otomatis dan realtime.

6. Sistem dapat menampilkan laporan logbook pengambilan barang, laporan stok peralatan, laporan stok pengharum \& chemical, laporan stok 
tissue, dan laporan logbook pengambilan barang per periodik.

7. Sistem dapat menampilkan grafik pengajuan barang dan detail pengajuan barang pada bulanbulan sebelumnya.

8. Sistem dapat mengexport data laporan pengajuan barang, laporan penggunaan barang dan laporan logbook.

9. Pengguna harus melakukan logout setelah selesai menggunakan aplikasi

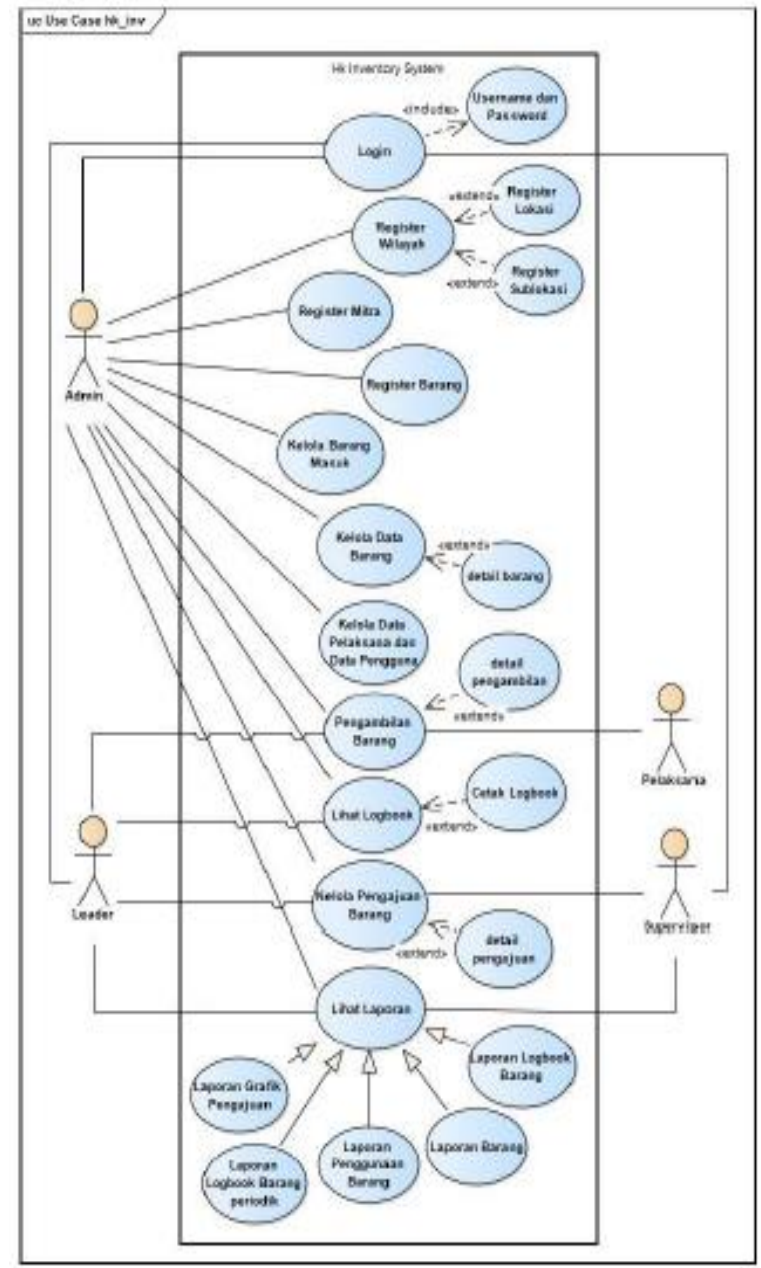

Gambar 5. Use Case Rancangan Sistem

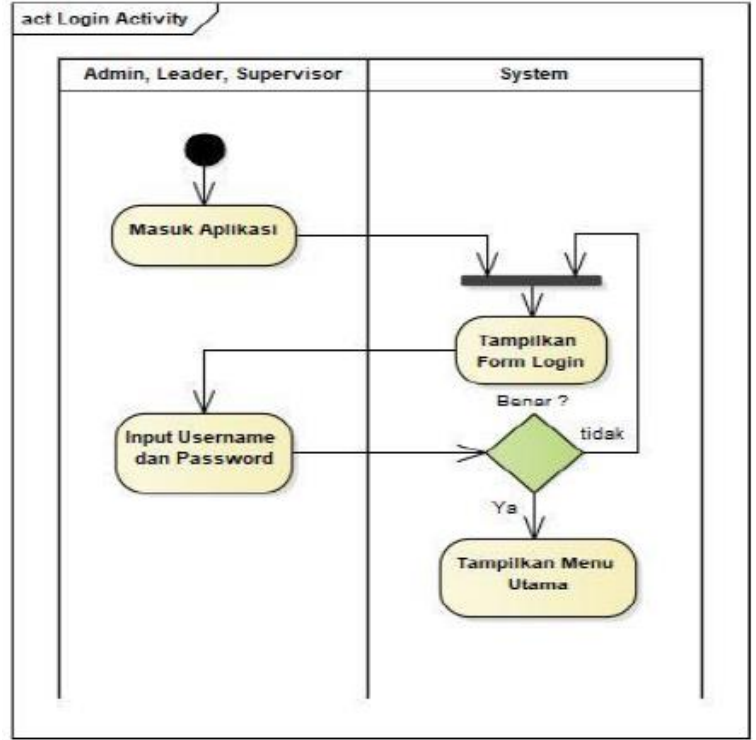

Gambar 6. Activity Diagram Login

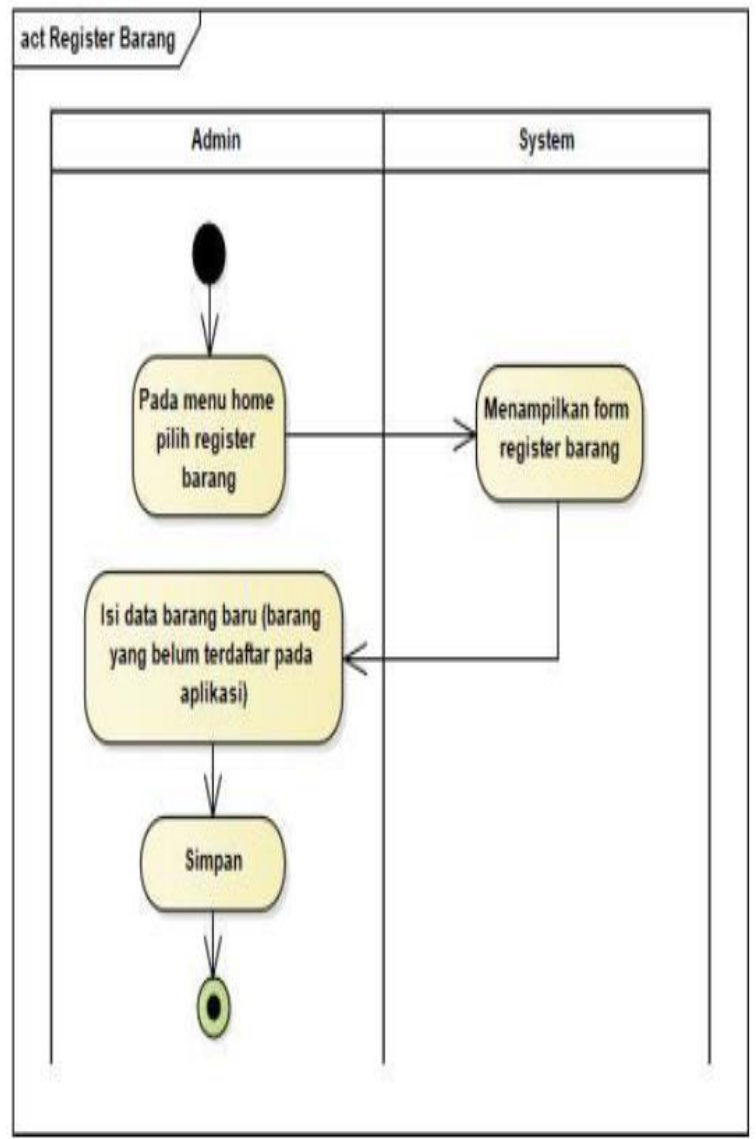

Gambar 7. Activity Register Barang 


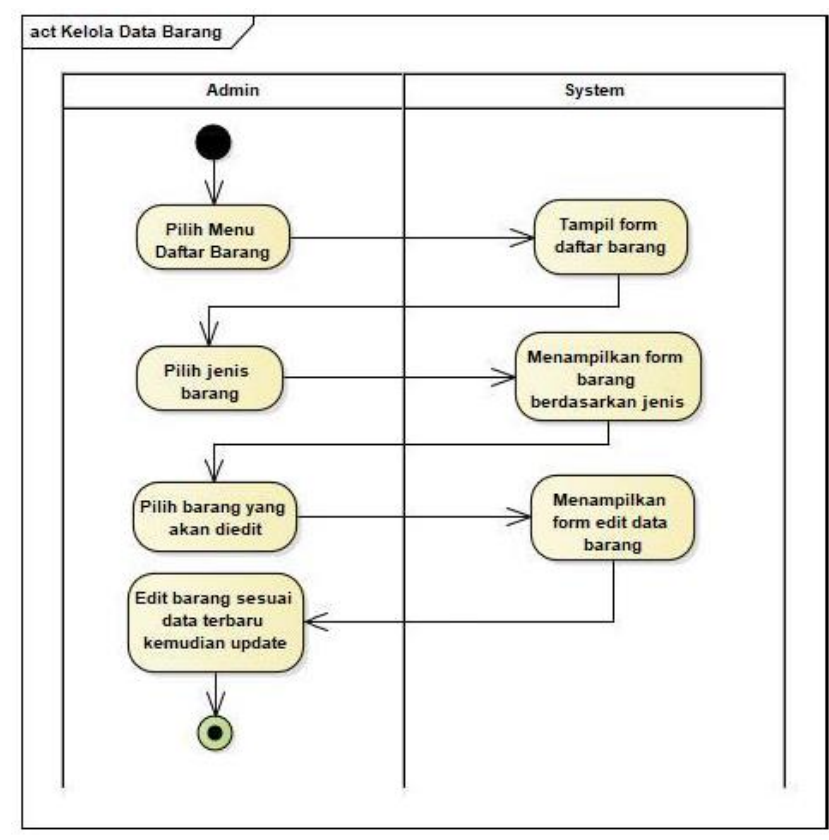

Gambar 8. Activity Diagram Kelola Data Barang

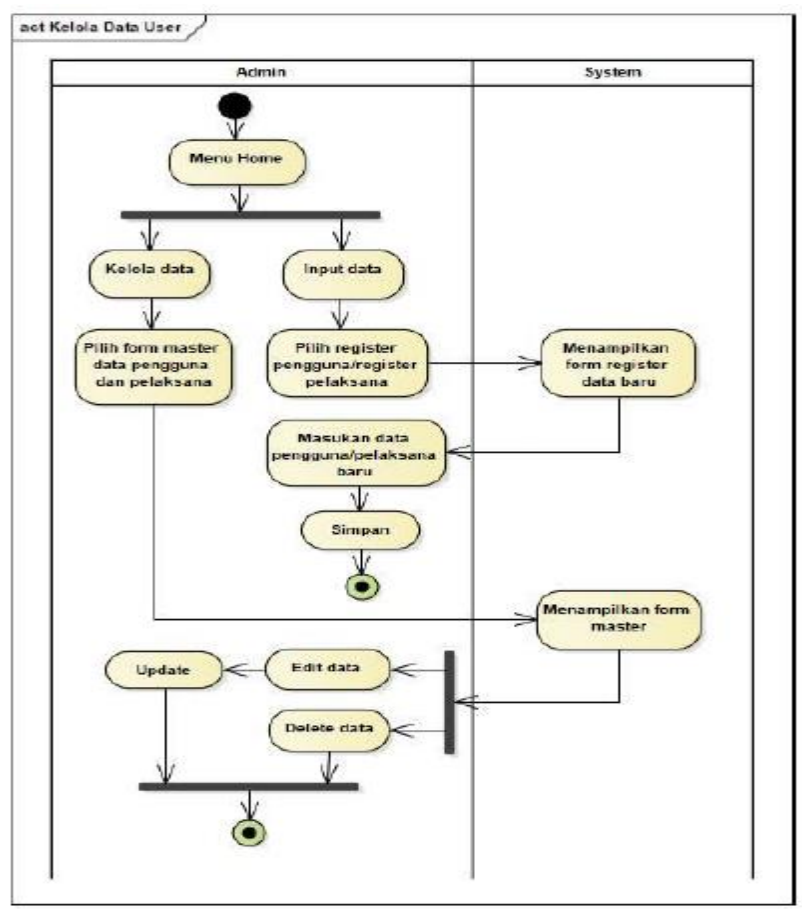

Gambar 9. Activity Diagram Kelola Kelola Data Pelaksana \& Data Pengguna

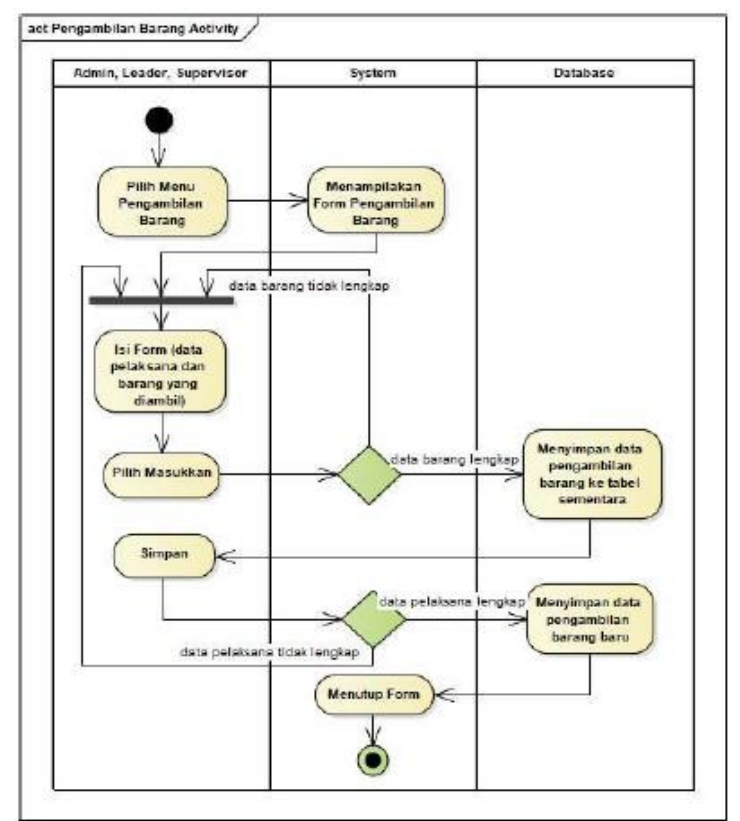

Gambar 10. Activity Diagram Kelola Data Pelaksana \& Data Pengguna

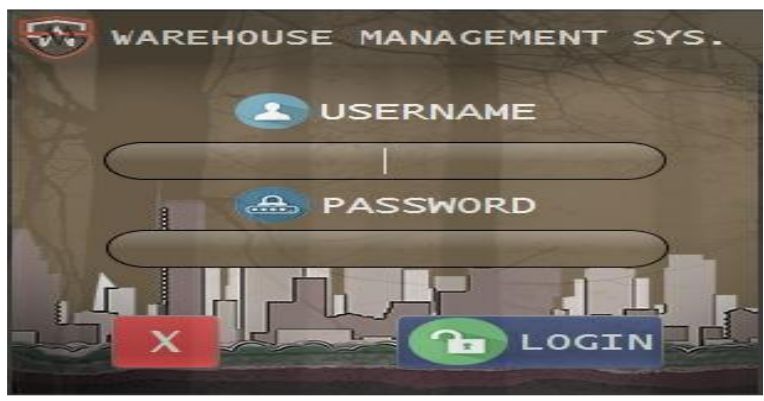

Gambar 11. Antar Muka Halaman Login

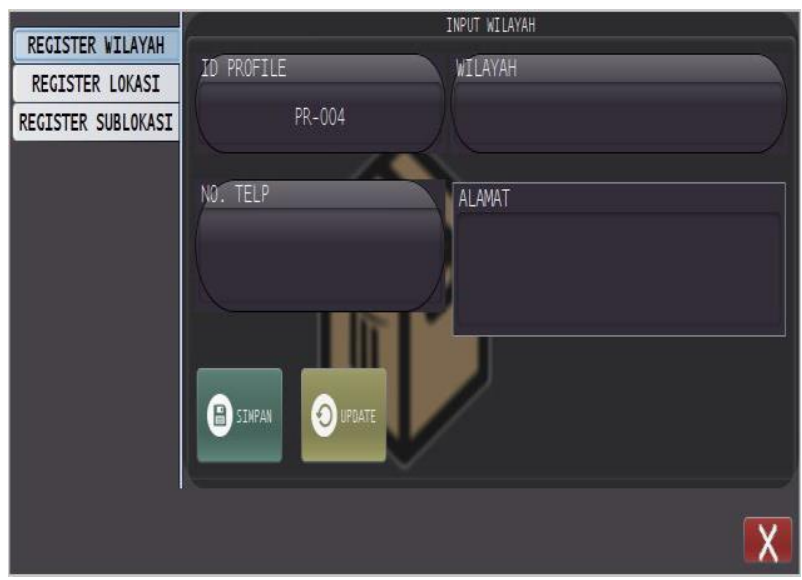

Gambar 12. Antar Muka Register 


\section{KESIMPULAN}

Berdasarkan uraian dan penjelasan sebelumnya, maka penulis mengambil kesimpulan sebagai berikut:

1. Dengan adanya aplikasi ini dapat memudahkan manajemen dalam memonitoring transaksi keluar masuk barang sehingga meminimalisir adanya disintegrasi dan ketidaksesuaian antara stok barang otentik dengan kondisi riil dilapangan.

2. Pencatatan transaksi barang menjadi efektif sehingga data dapat tersimpan secara berurutan, ringkas, dan terstruktur.

3. Pembuatan pengajuan barang menjadi lebih mudah dan efisien karena sistem melakukan kalkulasi total nominal secara otomatis.

4. Data laporan dari aplikasi ini dapat dijadikan sebagai sumber pengambilan keputusan bagi middle maupun top management dalam menentukan arah keuangan kedepannya khususnya efisiensi pengeluaran anggaran untuk barang.

\section{REFERENSI}

Bash, E. (2015). Pembangunan Sistem Aplikasi Penyewaan Mobil Berbasis Android Studi Kasus Di Cv Abu Sulaiman Rent Car. PhD Proposal, 1, $1-18$.

https://doi.org/10.1017/CBO9781107415324.004

Dahlan, A. (2018). Sistem Informasi Inventory Gudang Berbasis Website Pada Cv El'U Grafika. Sistem Informasi Inventory Gudang Berbasis Website Pada Cv El'U Grafika, 1(12141396), 14.

Harjunawati, S. (2017). Sistem Informasi Akuntansi Penjualan Berbasis Waterfall Model Untuk Perusahaan DagangHarjunawati, S. (2017). Sistem Informasi Akuntansi Penjualan Berbasis Waterfall Model Untuk Perusahaan Dagang. Indonesian Journal on Computer and Information Technology. . Indonesian Journal on Computer and Information Technology. https://doi.org/10.1016/01689002(90)90652-M

Hendini, A. (2016). Pemodelan UML sistem informasi Monitoring Penjualan dan stok barang. Pemodelan Uml Sistem Informasi Monitoring Penjualan Dan Stok Barang (Studi Kasus: Distro Zhezha Pontianak).

Heryanto1, A., Fuad2, H., \& Dananggi3, D. (2014). Rancang Bangun Sistem Informasi Inventory Barang Berbasis Web Studi Kasus di PT . Infinetworks Global Jakarta. Sisfotek Global.
Hutahaean, J. (2015). Konsep Sistem Informasi. In Konsep Sistem Informasi. https://doi.org/10.1017/CBO9781107415324.004

Indrajani. (2018). Database Systems All in One Theory, Practice, and Case Study. Jakarta: PT. Elex Media Komputindo.

Prastika, M. R. (2015). Sistem Informasi Rekapitulasi Pendapatan Pada Puskesmas Pembantu Sidomulyo. Journal Speed - Sentra Penelitian Engineering Dan Edukasi -, 7(1), 59-64. Retrieved from http://download.portalgaruda.org/article.php?articl $\mathrm{e}=269132 \& \mathrm{val}=7112 \&$ title=Sistem Informasi Rekapitulasi Pendapatan Pada Puskesmas Pembantu Sidomulyo Mirza Rida Prastika

Pratama, I. putu A. E. (2014). Sistem Informasi dan Implementasinya. In Informatika, bandung. https://doi.org/10.1051/0004-6361:20078778

Rosa, \& Salahuddin(2014:50). (2016). Perancangan Website Sebagai Media Informasi Panti Asuhan Batu Penjuru Kulon Progo. Journal Speed.

Rusmawan, U. (2019). Teknik Penulisan Tugas Akhir dan Skripsi Pemrograman. Jakarta: PT. Elex Media Komputindo.

Sasmito, G. W. (2017). Penerapan Metode Waterfall Pada Desain Sistem Informasi Geografis Industri Kabupaten Tegal. Jurnal Pengembangan IT, 2(1), 6-12.

Suwito. (2017). LRS. Widya Saputra, A., \& Bukhori, I. (2014). Kata Kunci : Pembangunan Sistem Informasi Penggajian SMP PGRI Kebonagung. $3(3), 6-10$. 